\title{
PRAKTYKI AUTOBIOGRAFICZNE
}

PIOTR LASKOWSKI*

Uniwersytet Warszawski

\section{Bunt i melancholia. Obraz życia anarchisty w Memuarn fun Lejbn}

\section{Streszczenie}

Artykuł poświęcony jest jedynej w swoim rodzaju narracji autobiograficznej - spisanej i opublikowanej w międzywojennej Polsce przez żydowskiego anarchistę. Niewielka książeczka Memuarn oder szpliters fun a lebn fun Lejbn (znana również jako Memuarn fun Lejbn) została wydana w 1933 roku w Łodzi, w 2017 roku ukazał się jej polski przekład pod tytułem Memuary albo okruchy z życia Lejba. W pierwszej części artykułu zidentyfikowano i przedstawiono postać autora, Lejba Berkenwalda, zwanego „Lejbem Anarchistą”, jego środowisko społeczne i usytuowanie na mapie międzywojennego anarchizmu. W części drugiej autobiograficzna narracja Lejba czytana jest w perspektywie mikrohistorii afektów; akcent położony został na wyłaniającą się z tekstu alternatywną formę męskiej podmiotowości - wykraczającą poza dominujący, heteronormatywny model męskości i przynależącą - tak w swych nadziejach, jak i rozczarowaniach - do niedającej się urzeczywistnić mesjańskiej wspólnoty.

\section{Słowa kluczowe}

Lejb Berkenwald, „Lejb Anarchista”, anarchizm żydowski, anarchoindywidualizm, historia afektów, queerstoria

\footnotetext{
* Kontakt z autorem: ptrlaskowski@gmail.com; ORCID: 0000-0001-9106-5499.
} 
Od początku XXI wieku historia żydowskiego anarchizmu na ziemiach polskich budzi rosnące zainteresowanie badaczy i badaczek. Przełomowe znaczenie miał niewątpliwie referat Daniela Grinberga, ojca polskich badań nad anarchizmem, wygłoszony na konferencji w Wenecji w maju 2000 roku i opublikowany w pokonferencyjnym tomie L'anarchico e l'ebreo. Storia di un incontro ${ }^{1}$. Sama kategoria „żydowskiego anarchizmu” rodzi dobrze znane wątpliwości, na które składają się z jednej strony szeroko rozumiana problematyka nowoczesnych przekształceń żydowskiej tożsamości, z drugiej zaś specyficzne trudności, jakie wiążą się z przykładaniem identyfikacji narodowej (lub religijnej) do ruchu ze swej istoty internacjonalistycznego i świeckiego. Kategorią mniej kłopotliwą, węższą, lecz dla potrzeb tego artykułu wystarczającą, jest „anarchizm jidyszowy”, wskazuje się tu bowiem na język używany przez określoną grupę anarchistek i anarchistów. Ów język określał zarazem społeczny kontekst ich działania, a także uniwersum kulturowe, stanowiące dla nich podstawowy punkt odniesienia. Nie oznacza to oczywiście, że jidyszowi anarchiści nie posługiwali się innymi językami (wielojęzyczność anarchistów to zresztą temat wart osobnego badania) i nie czytali innej niż jidyszowa literatury. Nie oznacza to również, że nie można mówić o żydowskim anarchizmie poza kręgiem osób mówiących w jidysz (choć pojawia się tu pytanie, co miałoby stanowić o specyfice owego anarchizmu. Czy wyróżniać miałyby go świadome odniesienia do tradycji judaistycznej, jak u Gustava Landauera, czy może samo tylko zakwalifikowanie pewnych działaczy jako Żydów? I dalej, czy podstawą takiej kwalifikacji musi być autoidentyfikacja, czy też mogą jej dokonywać - i wedle jakiego kryterium - badacze i badaczki? Wreszcie, czy nie należałoby mówić raczej o udziale Żydów w ruchu anarchistycznym? Czy fakt, że niektórzy anarchiści byli Żydami, miał jakiekolwiek znaczenie dla sposobu przeżywania przez nich idei anarchistycznej, jeśli - inaczej niż Landauer - nie czuli się oni związani z kulturą żydowską ani też nie działali „na żydowskiej ulicy”? Czy wolno podejrzewać, że nadawali oni myśleniu anarchistycznemu specyficzny kształt, już to za sprawą tradycji, którą wynieśli z domu rodzinnego, oddziałującej nawet gdy w sposób świadomy z nią później zerwali, już to za sprawą doświadczenia mniejszościowego?). Żeby rzecz skomplikować jeszcze bardziej, należy przypomnieć, że jeden z najważniejszych przedstawicieli anarchizmu jidyszowego,

1 Serdecznie dziękuję recenzent(k)om za krytyczne uwagi i niezwykle cenne tropy interpretacyjne i bibliograficzne, które uchroniły mnie przed wieloma błędami i pozwoliły znacznie wzbogacić ten artykuł. Błędy, których nie udało się wychwycić, obciążają oczywiście wyłącznie mnie samego. Daniel Grinberg, „Il radicalismo ebraico in Polonia", w: L'anarchico e l'ebreo. Storia di un incontro, red. Amedeo Bertolo (Milano: Elèuthera, 2001), 165-178; korzystam z przekładu francuskiego: tenże, „Formes de la militance juive radicale en Pologne”, w: Juifs et anarchistes. Histoire d'une rencontre, red. Amedeo Bertolo, tłum. Patricia Farazzi, Marianne Enckell, Jean-Manuel Traimond (Paris-Tel Aviv: Éditions de l’Eclat, 2008), 159-171; przekład polski: tenże, Radykalizm żydowski na ziemiach polskich: wyzwania i odpowiedzi, tłum. Łukasz Wilamowski (Mielec: Wydawnictwo Inny Świat: 2017). 
Rudolf Rocker, jeśli opisywać go w kategoriach narodowych, był Niemcem. Jakkolwiek ważne i szeroko dyskutowane, zagadnienia te nie mają kluczowego znaczenia dla tego artykułu. Będę tu bowiem zajmować się anarchistami mówiącymi i piszącymi w języku jidysz, zanurzonymi w żydowskim uniwersum kulturowym i żydowskim życiu społecznym.

W historii Polski jest to grupa wciąż mało znana. Znacznie więcej wiemy o anarchizmie jidyszowym w Rosji, Anglii czy w Stanach Zjednoczonych ${ }^{2}$, ale też na ziemiach polskich idee anarchistyczne nie zyskały nigdy choćby zbliżonej popularności. Pewne zakorzenienie społeczne zdobyły chyba tylko w zajmującym Grinberga okresie rewolucji 1905 roku właśnie wśród mówiących w jidysz młodych Żydów - między 15. a 20. rokiem życia - pochodzących ze środowisk rzemieślniczych i robotniczych ${ }^{3}$.

W porównaniu z rokiem 1905 ruch anarchistyczny w Polsce w interesującym nas tu dwudziestoleciu międzywojennym był zdecydowanie mniej liczny. Publikacje anarchistyczne ukazywały się wówczas przede wszystkim w języku polskim ${ }^{4}$. O ile więc w przypadku rewolucji 1905 roku możemy mówić o anarchizmie jidyszowym, o tyle w latach dwudziestych i trzydziestych anarchiści piszący w tym języku stanowili jedynie część, i to mniej widoczną, niewielkiego skądinąd ruchu.

Kontekstem przedstawionej tu analizy będzie działalność osób należących do specyficznego środowiska anarchistycznego. Ukształtowało się ono na początku lat dwudziestych

2 Zob. np. Paul Avrich, The Russian Anarchists (Princeton: Princeton University Press, 1967); Mosze Gonczarok, Piepiel naszich kostrow. Oczerki istorii jewriejskowo anarchistskowo dwiżenija (idisz-anarchizm) (Jerusalim: Izdatielstwo „Problemen”, 2002); Kenyon Zimmer, Immigrants against the State. Yiddish and Italian Anarchism in America (Urbana-Chicago-Springfield: University of Illinois Press, 2015) z doskonałą bibliografią; zob. też: John Patten, red., Yiddish Anarchist Bibliography (London-Cambridge: Kate Sharpley Library-Anarchist Archives Project, 1998). Najnowsze wyniki badań nad historią jidyszowego anarchizmu, przede wszystkim w Stanach Zjednoczonych i Rosji, przedstawiono na konferencji „Yiddish Anarchism: New Scholarship on a Forgotten Tradition" w YIVO w styczniu 2019 r. (program konferencji, dostęp sierpień 2020, https://yivo. org/cimages/2019_anarchismconference_program.pdf); udział w niej wzięli m.in. Kenyon Zimmer, a także Anna Elena Torres, której książka Any Minute Now The World Streams Over Its Border!: Anarchism and Yiddish Literature wkrótce ukaże się nakładem Yale University Press.

3 Grinberg, „Formes”, 169. Zob. też: Herman Rappaport, Anarchizm i anarchiści na ziemiach polskich do 1914 roku (Warszawa: Państwowe Wydawnictwo Naukowe, 1981).

4 O działalności anarchistów w pierwszych latach II RP, przed powołaniem w 1926 r. Anarchistycznej Federacji Polski, zob. Dariusz Wierzchoś, Michał Przyborowski, „Anarchizm polski w latach 1918-1926. Na drodze do utworzenia Anarchistycznej Federacji Polski”, Scripta Historica 22 (2016): 191-210. Zob. też: tychże, Machno w Polsce (Poznań: Oficyna Wydawnicza Bractwa Trojka, 2012). O ideologii i działalności AFP zob. Adrian Zandberg, „Anarchistyczna Federacja Polski. Polscy anarchiści w dwudziestoleciu międzywojennym”, Przegląd Historyczny 93 (2002), 1: 31-52. O AFP w kontekście polskiego syndykalizmu zob. Rafał Chwedoruk, Ruchy i myśl polityczna syndykalizmu w Polsce (Warszawa: Dom Wydawniczy Elipsa, 2011), 249-270; Grzegorz Zackiewicz, Syndykalizm w polskiej refleksji i rzeczywistości politycznej I połowy XX wieku (Kraków: Avalon, 2013), 213-216. 
wokół Arona Grossa, uczestnika ruchu anarchistycznego w dobie rewolucji 1905 roku, a po I wojnie światowej wykładowcy nauk judaistycznych w Gimnazjum Filologicznym Męskim Towarzystwa „Chinuch”. (Nauczanie w tej szkole prowadzono w językach polskim i hebrajskim; jej dyrektorem był w owym czasie Adam Cygielstrejch, wcześniej asystent w Instytucie Psychologicznym u Edwarda Abramowskiego, postaci ikonicznej dla polskiej myśli anarchistycznej $^{5}$ ). Uczniami Grossa byli między innymi Jerzy Borejsza, Salomon Filmus (później jeden z sekretarzy Anarchistycznej Federacji Polski, a po wojnie tłumacz dzieł młodego Marksa $^{6}$ ) oraz Eliezer Hirszauge, autor wspomnień kluczowych dla niniejszego artykułu. Do kręgu towarzyskiego Grossa należał również Hersz Menes, w początkach XX wieku aktywny w kręgach żydowskich anarchistów na londyńskim East Endzie, potem zaś w anarchistycznych komunach w Niemczech, a także Mojżesz Kaufman, działacz Żydowskiej Organizacji PPS w czasie rewolucji 1905 roku, w latach 1918-1928 związany z ruchem komunistycznym, który porzucił, by związać się z anarchistami.

Podstawowymi źródłami do badań nad żydowskim anarchizmem na ziemiach polskich są dokumenty policyjne, krótkie zazwyczaj wzmianki prasowe oraz niezbyt liczne gazety, odezwy i ulotki wydawane przez ruch. Relacji osobistych mamy bardzo niewiele. Jeśli chodzi o okres międzywojenny, szczególne znaczenie mają dwa teksty: wspomnienia Pawła Lwa Marka (dotyczące w zasadzie II wojny światowej, ale dostarczające wiedzy o postaciach, jak sam autor, kluczowych w ruchu przedwojennym) ${ }^{7}$ oraz opublikowana oryginalnie $\mathrm{w}$ jidysz w 1964 roku praca Eliezera Hirszaugego - bezcenna skarbnica informacji o jidyszowym anarchizmie w Polsce międzywojennej ${ }^{8}$. Jak zauważał sam Hirszauge, po Zagładzie nie ocalały niemal żadne ślady życia i działalności zamordowanych żydowskich anarchistów ${ }^{9}$.

Przedmiotem niniejszego opracowania jest bardzo szczególny tekst - zbeletryzowana autobiografia niemal zupełnie zapomnianego żydowskiego anarchisty z Łodzi, wyjątkowa choćby

5 Zob. Adam Cygielstrejch, „Twórczość psychologiczna Edwarda Abramowskiego”, Przegląd Filozoficzny 22 (1919): 1-12.

6 Karol Marks, Fryderyk Engels, „Święta rodzina, czyli krytyka krytycznej krytyki. Przeciwko Brunonowi Bauerowi i spółce", tłum. Salomon Filmus, Tadeusz Kroński, w: tychże, Dzieła, t. 2 (Warszawa: Książka i Wiedza, 1961), 3-262; ciż, „Ideologia niemiecka”, tłum. Salomon Filmus, Kazimierz Błeszyński, w: tychże, Dzieła, t. 3 (Warszawa: Książka i Wiedza, 1961), 9-619.

7 Paweł Lew Marek, Na krawędzi życia. Wspomnienia anarchisty 1943-44 (Kraków: Wydawnictwo „Dąb”, 2006). Wielką wartość ma dołączony do wspomnień suplement zawierający biogramy działaczy i działaczek anarchistycznych (295-308).

8 Eliezer Hirszauge, Trojm in farwirklechung (Tel Awiw: nakładem Diny Hirszauge, 1964); wydanie polskie: tenże, Spełniające się marzenie. Wspomnienia o ruchu anarchistycznym w Polsce 1928-1946, tłum. Magdalena Siek (Poznań: Oficyna Wydawnicza Bractwa Trojka, 2019).

9 Hirszauge, Spetniające, 16. 
dlatego, że została wydana jeszcze w okresie międzywojennym. Mowa o krótkiej, liczącej w oryginale 30 stron książeczce Memuarn oder szpliters fun a lebn fun Lejbn, znanej również jako Memuarn fun Lejbn, opublikowanej w 1933 roku. Przekład polski ukazał się w 2017 roku pod tytułem Memuary albo okruchy z życia Lejba ${ }^{10}$. Redaktorom polskiego wydania nie udało się zidentyfikować ani autora (uznali oni imię Lejb za pseudonim literacki nieznanej osoby), ani związków łączących ten tekst z anarchizmem.

Lejb

Autor autobiografii nie jest jednak postacią zupełnie nieznaną. W latach trzydziestych zyskał wręcz pewien rozgłos. Mówiono o nim po prostu „Lejb Anarchista” i pod tym imieniem pojawia się w kilku wspomnieniach. Istnieje nawet jego portret namalowany przez pochodzącego z Łodzi Jacoba Markiela (1911-2008), malarza od 1933 roku tworzącego w Paryżu ${ }^{11}$.

Nazywał się zapewne Lejb Berkenwald i za sprawą swojego pamiętnika doczekał się nawet krótkiego hasła w Leksikon fun der najer jidiszer literatur [Leksykonie współczesnej literatury żydowskiej]. Autorem hasła był Chaim Lejb Fuks (Chaim Leib Fox), który poświęcił też Lejbowi niewielki i bardzo podobny do opisu w Leksikonie fragment swoich łódzkich wspomnień ${ }^{12}$. W obu tekstach pojawiają się nazwisko (niepoświadczone w innych źródłach) oraz daty życia Lejba: 1898-1944.

Według Fuksa Lejb urodził się w Łodzi ${ }^{13}$ w rodzinie chasydzkiej. Imał się wielu niskopłatnych prac fizycznych, a przez zaangażowanie w ruch anarchistyczny miał kilkakrotnie trafić do łódzkiego więzienia ${ }^{14}$. We wspomnieniach o Łodzi Fuks pisze o Lejbie jako o słynnym oryginale, porównywalnym z „łódzkim Sokratesem” Chaimem Wodnikiem ${ }^{15}$. W 1939 roku Lejb przedostał się do Białegostoku. Informacji o jego pobycie w tym mieście dostarcza anonimowa

10 „Memuary albo okruchy z życia Lejba”, tłum. Anna Jakimszyn-Gadocha, w: Sztetl, szund, bunt i Palestyna. Antologia twórczości literackiej Żydów w Łodzi (1905-1939), red. Krystyna Radziszewska, Dariusz Dekiert, Ewa Wiatr (Łódź: Wydawnictwo Uniwersytetu Łódzkiego, 2017), 240-265.

11 Portret był wystawiany w Paryżu w 1948 r. Zob. Icchak Goldkorn, Lodżer portretn: umgekumene jidisze szrajber un tipn (Tel Awiw: Ha-Menora, 1963), 213-214. Reprodukcję opublikowano w wydawanym w jidysz paryskim piśmie „Almanach” (1955): 44.

12 Chaim Leib Fuks, Lodż szel majle (Tel Awiw: I.L. Perec Farlag, 1972), 153-154.

13 Goldkorn podaje, że Lejb urodził się w sztetlu Lutomiersk pod Łodzią (Lodżer, 207); sam Lejb w pamiętnikach wskazuje Kalisz („Memuary”, 241).

14 Informację o pobycie w więzieniu potwierdza sam Lejb, choć nie wiąże tego faktu z działalnością polityczną, mówi o celach, „do których przypadkiem trafiał” („Memuary”, 256).

15 O Chaimie Wodniku zob. Jechiel Jeszaja Trunk, Pojln. Obrazy i wspomnienia z Łodzi, tłum. Anna Clarke (Łódź: Wydawnictwo Tygiel Kultury, 1997), 111-113; Mosze Puławer, Ararat (Tel Awiw: I.L. Perec Farlag, 1972), 145-147, bezpośrednio przed wspomnieniem o Lejbie. 
relacja uchodźcy z Łodzi, zachowana w Archiwum Ringelbluma. „Lejb Anarchista” sportretowany jest tu bez sympatii jako „włóczęga, zawsze oberwany i brudny”. Autor zapamiętał go z Łodzi, z jadłodajni przy ulicy Południowej 20, gdzie otoczony znajomymi Lejb toczył spory i wygłaszał swe mądrości „nad zupą”. Istotnym wątkiem w tej relacji, pojawiającym się we wszystkich wspomnieniach o Lejbie, jest jego zamiłowanie do śpiewu. Przywołano tu nawet konkretne piosenki, które miał śpiewać już w Białymstoku, Córkę Weissenberga i Berjozkele Rejzena. O ile jednak w innych relacjach o pieśniach Lejba mówi się ze wzruszeniem, o tyle tu słyszymy, że budziły raczej szyderczy śmiech. Co ciekawe, wedle tej relacji Lejb miał być analfabetą. „Josef Okrutny napisał mu książkę, tzn. Lejb mówił, a Okrutny to spisał, później pomógł mu tę bezwartościową książkę wydać i sprzedawać. Ludzie śmiali się i płacili za książkę od 1 zł”" Wystarczyło to jednak, by w Białymstoku Lejb uzyskał wstęp do Klubu Pisarzy Żydowskich. Zarabiał tam, oddając przysługi innym pisarzom.

Wiele elementów tej relacji - oprócz śpiewu także spotkania w restauracji przy Południowej 20, pasja retoryczna, brak troski o wygląd zewnętrzny - znajdzie potwierdzenie w innych wspomnieniach. Nigdzie natomiast nie powtarza się informacja o analfabetyzmie Lejba (przeciwnie, zwykle mówi się o nim jako o człowieku oczytanym) i udziale Josefa Okrutnego, skądinąd znanego pisarza ${ }^{17}$, w tworzeniu pamiętników.

W haśle w Leksikonie Fuks podaje, że Lejb zmarł w obozie w okolicach miasta Syktywkar w Republice Komi w ZSRR ${ }^{18}$. W łódzkich wspomnieniach dodaje szczegóły: „W chwilach uniesienia [Lejb] rzucał strażnikom z NKWD słowa, jakich nigdy wcześniej nie słyszeli. Stalina nie tytułował inaczej, jak «gruzińskim chamem». Zapłacił za to własnym życiem”19.

Dłuższe, bardzo ciepłe wspomnienie o „Lejbie Anarchiście” pojawia się w książce Mosze Puławera poświęconej żydowskiemu teatrowi „Ararat” w Łodzi ${ }^{20}$. Autor kreśli sylwetkę niewysokiego, wychudzonego człowieka o częściowo sparaliżowanej twarzy i długich potarganych

16 Archiwum Ringelbluma. Konspiracyjne Archiwum Getta Warszawy, t. 3: Relacje z Kresów, oprac. Andrzej Żbikowski (Warszawa: Żydowski Instytut Historyczny IN-B, 2000), 83, tłumaczenie zmienione (por. tłum. ang.: The Ringelblum Archive. Underground Archive of the Warsaw Ghetto, vol. 2: Accounts from the Borderlands, 1939-1941 [Warszawa: Żydowski Instytut Historyczny, 2018], 116-117).

17 Josef Okrutny (1906-1991) - pseudonim Josefa Turki, ur. w Kutnie, pisarz i publicysta, w okresie międzywojennym mieszkał w Łodzi, wojnę przeżył w ZSRR, w latach 1946-1949 przygotowywał audycje radiowe w języku żydowskim dla Centralnego Komitetu Żydów w Polsce. W 1949 r. wyjechał z Polski, od 1951 r. mieszkał w Argentynie.

18 O pobycie Lejba w Białymstoku pisze również Icchak Goldkorn, autor wspomnienia, którym zajmiemy się niżej. Podaje, że Lejb, dla którego nawet życie w normalnych warunkach stanowiło źródło cierpienia, nie potrafił poradzić sobie w nowej sytuacji: „Jak słyszałem, zmarł z głodu i wycieńczenia w roku 1940” (Goldkorn, Lodżer, 213).

19 Fuks, Lodż, 154.

20 Puławer, Ararat, 147-149. 
włosach, stale niedojadającego, niedosypiającego, krążącego po ulicach Łodzi. „Wszyscy go lubili, nie zważając, że nigdy nie był dobrze ubrany, ani czysty (...). Nikt nie wiedział, gdzie mieszka, gdzie żyje, gdzie pracuje. Lejb więcej dyskutował niż pracował. Ale każdy miał do niego sentyment" 21 .

Lejb miał przesiadywać w kawiarni „Pod szklanką” przy ulicy Południowej 7. Kawiarnia, słynąca ze znakomitych naleśników, była miejscem spotkań „elementów postępowych i artystowskich”. Spotykali się tu artyści mało znani - ci bowiem, którzy odnieśli pewien sukces, wybierali „Astorię”22. Puławer zaznacza, że Lejb omijał ją jako zbyt elegancką. Ukuł nawet złośliwe określenie astoria-mencz, człowiek z „Astorii”, na określenie bogatych snobów. W „Pod szklanką” miał się trzymać ze studentami, którzy chętnie zapraszali go do stolika. Wdawał się z nimi w dyskusje, a gdy już zmęczyli się sporami, śpiewał.

Lejb jawi się w tym wspomnieniu jako człowiek bez reszty oddany muzyce. Miał znać na pamięć wszystkie możliwe pieśni robotnicze i ludowe. Śpiewał je z zaangażowaniem (mit harc un neszome $\left.{ }^{23}\right)$. Tworzył też własne pieśni, a także wykonywał całe fragmenty „klasyków” z repertuaru „Araratu”. Chodził tam często i podczas przedstawień „zatracał się w melodiach”24. Swoje wspomnienie Puławer kończy nutą melancholii: „Zawsze widziano go z plikiem pieśni pod pachą. Nosił je ze sobą i myślał o lepszym jutrze, które musi nadejść”25.

„Można powiedzieć, że Lejb żywił się chlebem z melodiami”, napisał Icchak Goldkorn, który w swoich wspomnieniach zachował słowa dwóch śpiewanych przez niego pieśni (drugą określił mianem „anarchistycznej”):

Jeszcze dziś dźwięczy mi w uszach serdeczny, melancholijny ton podróżnej pieśni śpiewanej przez Lejba:

Rozglądasz się wokół:

żadnego przyjaciela...

A ona, a ona,

A ona odeszła ${ }^{26} .(\ldots)$

\footnotetext{
21 Tamże, 148.

22 Krystyna Radziszewska, „Kultura i literatura łódzkich Żydów w okresie międzywojennym”, w: Sztetl, XXVIII.

23 Puławer, Ararat, 147.

24 Tamże, 148.

25 Tamże, 149.

26 Goldkorn, Lodżer, 210.
} 
W naszym świecie

dość już, dość:

całe rzeki pełne łez, wzgórza pełne płaczu.

Za łzy, które są naszą zapłatą,

czas nas uwieńczy koroną ${ }^{27}$.

Goldkorn podaje więcej szczegółów dotyczących kręgu znajomych Lejba, szczegółów istotnych, jak zobaczymy, w kontekście pamiętników. Mieli się oni spotykać całą kompanią przy alkoholu - zimą w piwiarniach, latem w lasach, na łonie natury. Lejb funkcjonował jako stały „oficer łącznikowy” zbierający razem towarzyszy - przede wszystkim młodych pisarzy, artystów, pracowników umysłowych. Ta anarchizująca żydowska bohema słuchała „gorących debat i monologów o... wolnej miłości, literaturze, filozofii, rewolucji społecznej, anarchokomunizmie i anarchosyndykalizmie - naszpikowanych niezliczonymi cytatami $\mathrm{z}$ anarchistycznych «poskim» ${ }^{28}$ - Bakunina, Stirnera, Godwina, Proudhona i innych”. Mimo żywych sporów, zauważa Goldkorn, „osobiste i ideologiczne dysonanse zanikały w harmonijnych akordach pieśni Lejba"29.

\section{Anarchista}

Z tymi ciepłymi wzmiankami wyraziście kontrastuje ton wspomnienia Hirszaugego ${ }^{30}$, którego przecież, zdawałoby się, łączył z Lejbem anarchistyczny światopogląd. Hirszauge nazywa go „Lejbem Anarchistą”, ale zaznacza, że to sam Lejb określał się tym mianem.

Hirszauge mieszkał w Łodzi w latach 1931-1932 i widywał Lejba w lokalach przy ulicy Południowej - nie w „Pod szklanką” jednak, lecz w „Robotniczym kącie” przy Południowej 20, w lokalu Bundu ${ }^{31}$. W Spełniającym się marzeniu Lejb przedstawiony jest jako człowiek oczytany w literaturze anarchistycznej, rzadko dopuszczający kogokolwiek do głosu, chętnie wygłaszający „uduchowione monologi”, które zazwyczaj wprawiały robotników w zakłopotanie. Hirszauge ocenia go surowo, choć nie bez współczucia:

\footnotetext{
27 Tamże, 211.
}

28 Pojsek (jid., l. mn. poskim) - autorytet rabiniczny rozstrzygający kontrowersje w kwestiach Halachy; osoba podejmująca decyzje.

${ }^{29}$ Goldkorn, Lodżer, 211.

30 Hirszauge, Spetniające, 57-59.

31 Znajduje to potwierdzenie w pamiętnikach Lejba („Memuary”, 248, 252-253) oraz, jak widzieliśmy, we wspomnieniu zachowanym w Archiwum Ringelbluma. 
Można było podejrzewać, że jego tragiczna przeszłość, która pozostawiła wyraźne ślady na jego ciele (powykręcane od paraliżu ręka i noga) i przekształciła go w biednego, niezdolnego do pracy człowieka, wyostrzyła w nim nienawiść do wszystkich i wszystkiego. W anarchizmie, który wygląda na to, że dobrze studiował, i który czasami był treścią jego życia i aktywnie go propagował, zapętlił się na wzór pająka, tak że nie widział już horyzontu społecznego ${ }^{32}$.

Dręczony poczuciem niezrozumienia, Lejb miał znajdować sympatyków wśród „nihilistycznie nastrojonych młodych ludzi”, kloszardów, „poetyckich dusz” - niekiedy niepozbawionych talentu - a także „przesyconych eksploatacją bogaczy, którzy jego i jego towarzystwo zapraszali na «wzniosłe» wieczory” ${ }^{33}$. Jak zauważa z goryczą Hirszauge, „ci «lejbiści» byli tak popularni jako «oryginały», że wystarczyło w towarzystwie bardzo przypadkowych łódzkich znajomych wypowiedzieć przypominającą anarchistyczną myśl, aby od razu pytano, czy jest się z ludzi «Lejba Anarchisty»"34.

Hirszauge zapoznał się z manuskryptem pamiętników Lejba jeszcze przed ich publikacją. Jak wspomina, nosiły one wówczas tytuł Memuarn fun Lejb anarchist [Pamiętniki Lejba Anarchisty].

Przy tej okazji w bardzo delikatny sposób dałem mu do zrozumienia, że jego interpretacja anarchizmu i zachowanie jego grupy przynosi szkodę propagandzie z wysiłkiem prowadzonej przez pionierskich towarzyszy naszego ruchu. Doradzałem mu usunąć z jego dzieła słowo „anarchista”, bo jego rozważania mają więcej związku z Lejbem niż z anarchizmem. W odpowiedzi spuścił głowę, schował ją w wychudzonych dłoniach. Kiedy odkrył twarz, dwie błyszczące łzy ześlizgnęły się po jego zachmurzonych policzkach. Wstając z impetem, jakby chciał uciec od samego siebie, przy pożegnaniu powiedział do mnie: „Każdy człowiek błądzi, a ja zbłądziłem na anarchistyczne drogi”. Chciałem odpowiedzieć: „Błądząc, nie należy innym pokazywać wątpliwych celów”, ale zniknął jak cień, zanim zdołałem otworzyć usta. Jak powiedzieli mi towarzysze z Łodzi, Pamiętniki Lejba Anarchisty ukazały się później drukiem. Zawierucha zagłady zmyła ślady Lejba razem z jego pamiętnikami ${ }^{35}$.

\footnotetext{
32 Hirszauge, Spetniające, 57.

33 Tamże, 58.

34 Tamże.

35 Tamże, 58-59.
} 
Jest rzeczą godną uwagi, że pamiętniki ukazały się pod tytułem niezawierającym słowa „anarchista”. Podobnie w ich treści nie pojawiają się żadne bezpośrednie odniesienia do anarchizmu, co musi zastanawiać, skoro w wielu wspomnieniach Lejb jawi się jako człowiek chętnie o nim rozprawiający. Czy Lejb zmienił tekst i tytuł na skutek rozmowy z Hirszaugem - nie wiemy.

W opublikowanym tekście Lejb raz tylko przedstawia się jako „socjalista”, a czyni to w sposób bardzo charakterystyczny:

Ja, niepraktyczny wagabunda, wiecznie błądzący i szukający życiowych mądrości, chorowity i sentymentalny, ciężko myślący marzyciel i fantasta, martwy już za życia - oto ja, to, co we mnie siedzi, produkt odrażającej litości, socjalista o burzliwej woli i zakrwawionych pięściach, kocham naturę, muzykę i każde żywe stworzenie (s. 241) ${ }^{36}$.

Nieco dalej zaś dodaje:

Czy ja sam przynoszę korzyści komuś ze swoimi do gruntu radykalnymi i filozoficznymi przemyśleniami i ideami? Czyż nie wymaga ode mnie czas (...) czegoś rewolucyjnego, to znaczy: stworzenia dzisiejszego męczennika rewolucji... Lecz ja jestem zapewne tylko bojaźliwym tchórzem z chorą duszą, chorą fantazją i chorym duchem, a efektem tego jest mój słaby, liryczny charakter (s. 254).

O kwestiach politycznych Lejb mówi jeszcze dwukrotnie, za każdym razem są to uwagi enigmatyczne i odnoszące się do dalekiej już przeszłości. Opisując swoje życie w Łodzi w roku 1917, wspomina: „Zostałem wciągnięty w życie społeczne, obracałem się w kręgach robotniczych, często bywałem w związkach, zaglądałem do literatury z zakresu ekonomii i historii oraz z zapałem czytałem o ruchach wolnościowych czy rewolucjach” (s. 245). Druga wzmianka dotyczy roku 1920: „stałem się częstym gościem stowarzyszeń, w których pełen młodzieńczego zapału i naiwności brałem udział w dyskusjach na tematy polityczne” (s. 246).

Co ciekawe, między rokiem 1918 a 1920 Lejb brał udział w wojnie polsko-bolszewickiej. Ale i ten temat potraktował w pamiętnikach skrótowo: „W 1918 roku zaciągnąłem się do szeregów, które w większości tworzyli siedemnasto- i osiemnastoletni chłopcy. Ale to jest historia, na którą nie ma tu miejsca” (s. 245).

36 Tu i dalej cytuję „Memuary” Lejba za: Sztetl, podając numer strony bezpośrednio po cytacie. 
Choć w pamiętnikach Lejba nie znajdujemy bezpośrednich odwołań do anarchizmu, ich treść oraz informacje ze wspomnień o Lejbie pozwalają chyba wyjaśnić zdystansowanie czy nawet niechęć Hirszaugego.

Hirszauge należał do działaczy silnie sympatyzujących z syndykalizmem. Nurt ten jawił się wielu anarchistom pierwszych dekad XX wieku jako urzeczywistnienie anarchistycznych marzeń. Większość anarchistów zgadzała się, że należy się włączyć w działania syndykatów. Różnili się jedynie co do tego, czy anarchizm bez reszty spełnia się w syndykalizmie, czy też jest czymś więcej. Do kluczowej debaty na ten temat doszło na kongresie anarchistycznym w Amsterdamie w 1907 roku. Młody, dwudziestopięcioletni Pierre Monatte ogłosił tam, że anarchiści, o ile nie chcą „strzec popiołów anarchizmu, lecz jego płomienia”, winni bez reszty poświęcić się działalności syndykalistycznej, którą anarchizm wraz z innymi nurtami socjalizmu przygotował i za sprawą której przestał być jedynie słowem, „filozoficzną spekulacją w wieży z kości słoniowej”. Monatte wzywał zatem: L'anarchie est morte! Vive l'anarchie! ${ }^{37}$.

Polemikę z Monattem podjął nestor anarchizmu, dawny towarzysz Bakunina, Errico Malatesta. Nie kwestionował zasadności działania w syndykatach, zwracał jednak uwagę, że praktyka syndykalistyczna jest jedynie środkiem, anarchia zaś celem.

Anarchistyczna rewolucja, jakiej chcemy, znacznie przekracza interesy klasowe: przedstawia całkowite wyzwolenie tkwiącej dzisiaj w poddaństwie ludzkości, ujmowane z trzech punktów widzenia: ekonomicznego, politycznego i moralnego. Zachowujmy więc ostrożność wobec wszelkich środków działania jednorodnego i uproszczonego. Syndykalizm, doskonały środek działania wiążący nas z klasą robotniczą, nie może być naszym jedynym środkiem. A tym bardziej nie może sprawiać, byśmy stracili z oczu jedyny cel warty zabiegów: anarchię $e^{38}$.

To samo napięcie, o podobnym wymiarze pokoleniowym, dostrzegamy wśród międzywojennych żydowskich anarchistów w Polsce. Hirszauge wspominał:

Ruch anarcho-syndykalistyczny (...) często postrzegany jest przez inne nurty anarchistyczne (...) jako nasz ruch „młodzieżowy” właśnie ze względu na jego dynamizm. Tak zwani „starzy” uważają za swoją powinność iść z prądem młodości, trwając przy zadaniu podnoszenia anarchistycznego ducha w syndykalistycznych szeregach. Mimo ideologicznych

37 Zob. Jean Maitron, Le mouvement anarchiste en France, t. 1: Des origines à 1914 (Paris: Gallimard, 1975), 326-327.

38 Errico Malatesta, „Lo sciopero armato”. Il lungo esilio londinese 1900-1913 (Milano: Zero in Condotta, 2015), 184. 
różnic panuje we wszystkich krajach harmonijna współpraca między tymi dwoma głównymi kierunkami. Zapał grup syndykalistycznych, ich starania organizacyjne na obszarze zawodowym wywołują najwyższe uznanie również u tych, którzy chcą widzieć w anarchizmie, nawet w jego fazie walki, ponadklasową ramę ${ }^{39}$.

Do „starych” Hirszauge zaliczał Hersza Menesa i Mojżesza Kaufmana, którym poświęcił osobne rozdziały swych wspomnień. Obaj, jak zobaczymy, wypowiadać się będą niekiedy w tonie lub formach bliskich pisarstwu Lejba, jakkolwiek ideowo zdecydowanie bliżej było im do Hirszaugego.

I „starzy”, i „młodzi” co do zasady sympatyzowali z syndykalizmem. Równolegle jednak z jego powstaniem ukształtowała się w łonie anarchizmu doktryna czy postawa bezwzględnie wobec niego krytyczna - anarchoindywidualizm. Indywidualiści odrzucali perspektywę społeczną. „Konsekwentny anarchizm mógł być - ich zdaniem - zbudowany wyłącznie na indywidualistycznych podstawach, albowiem społeczeństwo, w nie mniejszym stopniu niż aparat państwowy, traktowali jako źródło zniewolenia jednostek"40.

Zdaje się, iż anarchizm Lejba był silnie naznaczony tą perspektywą - sam Hirszauge zauważa, że Lejb „nie widział już horyzontu społecznego”. Jest rzeczą uderzającą, że Lejb rozpoczyna swoje pamiętniki od rozważań stanowiących, jak się wydaje, medytację nad nieprzywołanymi wprost słowami Goethego, którymi Max Stirner, uznawany przez anarchoindywidualistów za ideowego ojca i mistrza, otwiera i zamyka swe główne dzieło zatytułowane Jedyny i jego własność: „Swoją sprawę oparłem na nicości”.

Lejb zaczyna:

Kim jestem? Sam tego nie wiem (...). Ja, małość i wielkie zero, pustka jedynie, tak potężna, że wysysająca szpik z kości (...). Od kiedy pamiętam, widzę siebie jako dwunożną istotę, zawsze w opozycji do wszystkiego, co mnie otacza, do tego, co rzekomo tak mnie zajmuje (...). Więc dalej pytacie, kim jestem? Pewne jest, iż nie jestem żadną ważną personą, lecz szarym człowiekiem, nieprzynależącym do żadnej grupy społecznej - albowiem społeczeństwo dzieli się na kupców, rzemieślników, fabrykantów, maklerów, urzędników, złodziei, inteligentów, „tych powyżej dziesięciu tysięcy” i milionową rzeszę proletariuszy. No tak, jest jeszcze jedna grupa - obdartusów, albo... Nie mam możliwości wkupić się do żadnej z tych grup. Jestem - co wy mówicie: jestem? (s. 240-241)

39 Hirszauge, Spetniające, 20; podkr. oryg.

40 Daniel Grinberg, Ruch anarchistyczny w Europie Zachodniej 1870-1914 (Warszawa: Wydawnictwo Naukowe PWN, 1994), 146. 
Rozpoznanie nicości wiedzie do zerwania więzów ze społeczeństwem - także z „milionową rzeszą proletariuszy” czy lumpenproletariackimi „obdartusami”. Nieprzynależenie pozbawia wszelkich cech czy własności - zawsze jest się tylko „dwunożną istotą”, człowiekiem „szarym”.

To jednak, co dla anarchoindywidualistów jest punktem wyjścia do jednostkowej egzystencji wyzwolonej z pęt społecznych norm i humanistycznych ideałów, dla Lejba stanowi źródło cierpienia. Dobry wykład światopoglądu anarchoindywidualistycznego znajdujemy w do pewnego stopnia autobiograficznej powieści Johna Henry’ego Mackaya Die Anarchisten: Kulturgemälde aus dem Ende des XIX Jahrhunderts (1891). Autor, szkocko-niemiecki poeta i myśliciel, wydobył z zapomnienia myśl Stirnera i był jednym z najbardziej wpływowych anarchoindywidualistów. W Die Anarchisten jeden z bohaterów, Carrard Auban, jak się wydaje porte-parole autora, odrzuca anarchistyczny ideał społecznej harmonii (reprezentowany przez Ottona Truppa), nie wierzy bowiem w jakikolwiek powszechny model szczęścia. Każdy taki model z konieczności sprowadza się do narzucenia wszystkim przekutego w ideał pragnienia, które z natury rzeczy zawsze jest jednostkowe. Drogą wyzwolenia od straszliwej nędzy będącej skutkiem działania rządów może więc być jedynie indywidualna odmowa uczestnictwa w odgórnie zorganizowanym społeczeństwie. Na pierwszy rzut oka koresponduje to z postawą Lejba, który nie chce, nie potrafi stać się „dzisiejszym męczennikiem rewolucji”. Ale u Mackaya wycofanie się jest przejawem siły, u Lejba - skutkiem słabości: „Mój duch jest słaby, jestem odpadkiem, kaleką, nieudacznikiem, który marnuje tylko bez sensu chleb na tej ziemi” (s. 255).

Anarchiści, którzy przyjmowali perspektywę społeczną, nawet jeśli zachowywali dystans do syndykalizmu, nie znajdowali z anarchoindywidualizmem punktów wspólnych. Ich poglądy najdobitniej wyraził Jean Grave, centralna postać francuskiego anarchizmu przełomu wieków. Twierdził, że przeciwstawienie jednostki społeczeństwu oznacza absolutyzację konfliktu między indywidualnym a wspólnotowym, tymczasem konflikt ten jest pochodną obecnego sposobu zorganizowania społeczeństwa przez władzę. W społeczeństwie wyzwolonym wspólnota stanie się środowiskiem, nie przeszkodą w rozwoju jednostki:

Zwalczaliśmy państwo, całość społeczną, odzyskiwaliśmy wolność rozwoju dla jednostki, lecz natychmiast niektórzy zaczęli wywyższać całość-jednostkę, głosząc najpełniejszą autonomię bytu ludzkiego, rozumując tak, jakby ów byt, owa jednostka istniała sama we wszechświecie (...). Taki sposób ujmowania jednostki jako całości odsyła - jeśli doprowadzimy to rozumowanie do logicznych konkluzji - do antagonizmu społecznego, który zamierzaliśmy zniszczyć wraz ze zniszczeniem obecnej organizacji społecznej. Oto błąd 
jednostek w rodzaju (...) Mackaya. Ponadto taki sposób ujmowania tej kwestii jest jedynie przekształceniem ducha arystokratycznego... ${ }^{41}$

W wypadku Mackaya chodzi jednak nie tyle o antagonizm, ile o oddzielenie, zapewne naznaczone pogardą. Jednostka nie walczy tu ze społeczeństwem, a tylko mu się nie narzuca, żądając wzajemności. U Lejba, u którego nicość i pustka stanowią o nieprzynależeniu do jakiejkolwiek społecznej całości, relacja ze społeczeństwem jest bardziej złożona. Składają się na nią i głęboka niechęć, którą Hirszauge rozpoznał jako „nienawiść do wszystkich i wszystkiego", i samotnicza twórczość literacka, i - wreszcie - tęsknota za wielką, rewolucyjną zmianą: „być może pod kupą gnoju mej kruchości i rozpadu tli się jeszcze iskra tego, co tworzy pisarza, rewolucjonistę lub mordercę!” (s. 254). Nie jest bez znaczenia, że w swoim pokoiku Lejb powiesił portrety Kropotkina i Marksa.

Anarchoindywidualiści nie odrzucali zresztą myśli o życiu wspólnotowym. Lecz wspólnoty, które tworzyli, miały specyficzny charakter. Victor Serge pisał: „Nie czekać na rewolucję. Prorocy rewolucji są takimi błaznami, jak wszyscy inni. Robić samemu swoją rewolucję. Być człowiekiem wolnym, żyć w koleżeństwie (en camaraderie)”42.

Zamiast rewolucji społecznej - rewolucja indywidualnego życia. Ta idea koleżeństwa ludzi wolnych, oddzielonych od istniejącego społeczeństwa, miała w sobie rzeczywiście pierwiastek arystokratyczny, trafnie rozpoznany przez Grave’a. Nic więc dziwnego, że apelowała do wyobraźni artystowskiej bohemy, zwłaszcza twórców nieznajdujących uznania wśród mieszczańskiej publiczności. Artyści tacy, łączący pogardę dla „filistrów” z przekonaniem o własnej wyjątkowości, epatowali bourgeois, zadając się z kloszardami i przesiadując w tanich barach. W takim właśnie środowisku Lejb próbował, jako „oficer łącznikowy”, urzeczywistniać anarchoindywidualistyczną camaraderie. Kluczowe fragmenty pamiętników poświęcone są klęsce tych starań.

\section{Cierpienie}

Narrator pamiętników Lejba jest człowiekiem głęboko nieszczęśliwym, a rytm jego opowieści wyznaczają kolejne spadające na niego ciosy. „Jeśli jest się przeznaczonym do udręki, bólu i cierpienia nigdy nie zabraknie (...). Moje cierpienie zaczęło się od bolesnych narodzin i trwa po dziś dzień” (s. 253). W pierwszej części Lejb skupia się na brutalności panującego

\footnotetext{
41 Jean Grave, L'individu et la société (Paris: P.-V. Stock, 1897), 87-88.

42 Victor Serge, „Meditation sur l'anarchie”, Esprit 55 (1937); cyt za: Maitron, Le mouvement, 423.
} 
porządku ekonomicznego i koszmarze nędzy, w drugiej - na niepowodzeniach w tworzeniu artystowskiej camaraderie i pogłębiającym się poczuciu osamotnienia.

Oto więc rosyjski rewirowy prześladuje nauczającego nielegalnie ojca Lejba. Sam Lejb jako dziecko zapada na kolejne choroby, które trwale go okaleczają. Niezdolny do pracy fizycznej, terminuje bez powodzenia u garbarza, krawca, piekarza. W czasie I wojny światowej zmuszony jest zatrudnić się przy karczunku lasu i kopaniu rowów. „Zupełnie osłabłem, a goje wyśmiewali się ze mnie" (s. 245). Potem jest pomocnikiem malarskim, pracuje w fabryce cukru. Wreszcie znajduje przystań w należącym do rodziny Futermanów sklepie firmy „Jutalen” przy Piotrkowskiej 60 (s. 248, 251) (3) $^{4}$

Lejb poznaje Futermanów jeszcze jako chłopiec. Z polecenia ojca, który jest u nich mełamedem, opiekuje się ich cierpiącym na suchoty synem: „Jako pobożne i szlachetne dziecko pozostawiono mnie z chorym chłopcem, któremu miałem usługiwać. Dzięki temu mogłem stołować się i spać w domu bogacza” (s. 244). Po wielu latach zatrudnia się w ich sklepie. Praca jest ciężka, nużąca i nisko płatna, Lejb nie dojada, nie ma gdzie mieszkać, nocuje zamknięty w sklepie, ale właściciele od czasu do czasu okazują mu litość naznaczoną paternalistyczną wyższością: „Tak, dzieci tego bogacza F. uwielbiają być dobroczyńcami. Starsi biorą mnie często do swojej izby, podejmują posiłkami; częstują śniadaniem, obiadem i herbatą. W każdy piątek noszę panu Ch.M.F. obiad do sklepu. Z tego powodu pani F.F. też podaje mi obiad" (s. 250).

Wkrótce „Jutalen” przechodzi w nowe ręce, a nowy szef okazuje się

duszą pozbawioną sumienia, krwiopijcą, który nie ma serca dla pracującego dlań człowieka, pozwalając mu chodzić głodnym, wpędzając go w gruźlicę, nie płacąc mu za pracę, upokarzając na każdym kroku. U niego byłem nie tylko bez chleba, lecz także nigdy się nie goliłem, nie strzygłem, nie miałem pieniędzy na kąpiel, miałem dziurawe buty i podarte spodnie (s. 252).

Tu kończy się część pierwsza. Przenosimy się teraz do mieszkania Lejba. „Całe moje wędrowne życie poświęciłem zdobyciu dachu nad głową” (s. 256). To ciemna komórka przy ulicy, którą Lejb nazywa „Kloaczną”, miejscu „najczarniejszej biedy i upadku”. Widzimy „niski, czarny i podziurawiony sufit, ściany pełne śladów pluskiew i mokre «ślimaki» zacieków. Para posklejanych desek na dwóch skrzynkach po pomarańczach to moje łóżko” (s. 256).

\footnotetext{
43 Sklep o takiej nazwie rzeczywiście od $1923 \mathrm{r}$. znajdował się pod tym adresem i należał do rodziny o tym nazwisku. Zob. Podręczny rejestr handlowy 1926 (Łódź: Nakładem Wydawnictwa Księgi Prawomocnych Podpisów Przemysłu, Handlu i Finansów, 1926), 28.
} 
W tym właśnie miejscu tworzą się zalążki specyficznej wspólnoty. Icchak Goldkorn określa ją słowem chewre - bractwo, towarzystwo, kompania, innymi słowy: camaraderie - i wspomina, że pamiętniki Lejba zrodziły się z „rozczarowania i rozgoryczenia” towarzyszami, którzy szybko zmienili się w „przeciwników” ${ }^{44}$. Lejb z gorzką ironią, która pozwala widzieć ostro, kreśli kolejne portrety. Jest tu pozujący na Raskolnikowa cynik „Garewicz, młodzieniec w czarnej pelerynie (...), chodził po ulicach i starał się wyglądać jak bohaterowie literatury, którą się zaczytywał” (s. 257). Jest Josel W., który „pił wszystko, kokietując przy tym i głosząc alkoholizm. Usprawiedliwiał się, powołując na Baudelaire’a, który w końcu też pił. Sam co prawda Baudelaire’a nie czytał (...), lecz nie przeszkadzało mu to mówić «przyjacielsko», intymnie: «Charles, mój Charles»”. Kolejna postać to Szajele K.: „Prowadzi się ze swatkami na jemu znane zabawy i wesela, na które go proszą jako wesołka i wodzireja. On tam śpiewa, deklamuje, monologuje i wygłupia się”. Dalej jest Hilel Rawer, co „biega po ulicy, by sobie zapewnić powodzenie i kolekcjonuje coraz to nowe dziewczęta” (s. 258). I jeszcze:

Szalom z wielką poetycką burzą włosów (...) prowadził analizy psychiatryczne nas wszystkich, twierdząc, że jest psychologiem i znawcą ludzi. Cygan kręci się z pretensjami do całego świata, z brzuchem pełnym najgłębszego bólu istnienia, lecz chyba nie wie, czego chce i obdarza wszystkich cynicznym, śmiesznym i monotonnym ziewnięciem. Czarnej dziewczynie zaś, co się do niego kleiła, głosi nihilizm. Diamant ceni jednostkę, pluje na świat i pisze gigantyczną powieść - romans i poemat zarazem, która wstrząśnie światem; słowem - nieujawniony geniusz (s. 259).

Lejb stara się podtrzymać tę wspólnotę wyrzutków: „Dzieliłem się z nimi chlebem, ustępowałem posłania, moje serce ćwiartowałem i rozdawałem między ludzi, którzy byli mi bliscy z uwagi na ich prawdziwe lub udawane podobieństwo do mnie i do mojego położenia” (s. 256-257). Dokłada starań, przypomnijmy wspomnienie Goldkorna, by „dysonanse zanikały w harmonijnych akordach” jego pieśni. Ale oczywiście ta przedziwna koleżeńska komuna, chewra, musi się rozpaść. Jedni odchodzą sami, „dezerterują”, z innymi dochodzi do nieuchronnych konfliktów: „Josel W. i Hercke byli na mnie źli, że nie pozwoliłem przekształcić mojej skromnej izby w karczmę z pijaństwem i awanturami (...). Lolek z Gerszonem byli na mnie źli, ponieważ nie pozwoliłem dłużej robić z mojej izby burdelu” (s. 257).

Rozpacz związana z niemożnością zaistnienia anarchistycznej wspólnoty dotyka także „starych” - anarchistów przyjmujących perspektywę społeczną. O jednym z nich, Herszu Menesie, pisze Hirszauge: „Uczestniczył w eksperymentalnych koloniach anarchistycznych w Niemczech, o których napisał obszerniejszą pracę w formie powieści. Opisywał w niej

44 Goldkorn, Lodżer, 213. 
przede wszystkim psychologiczne trudności, jakie ujawniały się we wspólnym życiu tego wzorcowego kolektywu" ${ }^{45}$. Powieść Menesa niestety się nie zachowała, znamy natomiast jego listy, które w 1936 roku wysyłał do Hiszpanii, pragnąc dołączyć do anarchistycznej rewolucji:

Jestem samotnym człowiekiem po czterdziestce, nadal gotowym i chcącym pracować ciężko na życie, pracować fizycznie w przemyśle skórzanym. Ale też dalej chcę pracować dla wspólnej sprawy i wiecie, że będę potrafił to robić. Nie oczekuję kwiatów ani łatwego życia. Oczekuję użytecznej pracy dla naszego ideału. Ocalcie mnie od nieszczęścia! Ocalcie mnie od samotności i bezczynności! Pozwólcie mi schronić się pośród was ${ }^{46}$.

Anarchistyczne marzenie o wspólnocie, wciąż na nowo ożywiane przez ideał, nieustannie konfrontowane jest z osamotnieniem i goryczą wywołaną niepowodzeniami w jej urzeczywistnianiu.

\section{Religijność}

Marzenie o wspólnocie, które odnajdujemy u jidyszowych anarchistów, ma w sobie element mesjański. Mojżesz Kaufman, kolejny obok Menesa „stary”, któremu Hirszauge poświęcił rozdział swych wspomnień, malarz pokojowy, a u kresu życia, w latach trzydziestych, dziejopis Żydowskiej Organizacji PPS, w jednym ze swoich opracowań historycznych pomieścił relację pewnego towarzysza ze zorganizowanej przed wielu, wielu laty, w 1895 roku, wspólnej polsko-żydowskiej demonstracji w Tisza be-Aw - w dniu postu i żałoby upamiętniającym zburzenie pierwszej i drugiej Świątyni Jerozolimskiej:

Kiedy się przyglądałem temu, jak chrześcijańscy i żydowscy robotnicy jedzą i piją razem, nazywają się wzajemnie towarzyszami, spoglądają sobie przyjaźnie w oczy, jak żydowscy młodzieńcy w długich kapotach tańczyli z chrześcijańskimi dziewczętami, to zapomniałem o rzeczywistym życiu. Zdawało mi się, że już nadszedł (...) dzień Mesjasza, „kiedy zgoda panować będzie na całym świecie i lew będzie się pasł razem z owieczką" ${ }^{47}$.

Wspólnota opisywana przez Kaufmana łączy robotników w politycznej walce, która unieważnia i znosi bariery religijne i narodowe. Co ciekawe, przywołana przezeń demonstracja została zorganizowana przez PPS; wydaje się, że Kaufman, który porzucił szeregi PPS,

\footnotetext{
45 Hirszauge, Spełniające, 31-32.

46 International Institute of Social History w Amsterdamie, Federación Anarquista Ibérica Archives, Archivo de la oficina de propaganda exterior CNT/FAI, Augustin Souchy, sygn. 41D, List w języku angielskim.

47 Mojżesz Kaufman, „Początki roboty żydowskiej PPS”, Niepodległość 7 (1933): 340.
} 
przeszedł do komunistów, a w latach trzydziestych zwrócił się ku anarchizmowi, kierował się stale pragnieniem urzeczywistnienia takiej właśnie wspólnoty. Nie ulega wątpliwości, że różni się ona fundamentalnie od anarchoindywidualistycznych camaraderies, fakt ujęcia jej w kategoriach mesjańskich jest jednak o tyle interesujący, że również Lejb do opisania swojej wspólnoty używa języka religijnego. Tym, co ją spaja, nie jest, rzecz jasna, przynależność klasowa, lecz miłość. Zauważmy wszakże, że także w słowach cytowanych przez Kaufmana więcej jest miłości niż proletariackiej walki. Lejb definiuje miłość zarazem jako słabość, prowadzi ona bowiem do cierpienia, i jako siłę zdolną przekształcić świat:

Czy na pewno sentymenty, uczucie, serce, dusza, miłość, cierpienie, a nawet ludzka „płaczliwość” są słabością? Czyż to właśnie cierpienie nie powoduje, że drży wszystkie siedem niebios wraz z aniołami? Czyż Chrystus nie jest idealnym wzorcem cierpienia i miłości? A chasydyzm rebego Nachmana z Bracławia - czyż nie jest pełen miłości do Boga? Czy Zaratustra nie jest pełny miłości? (...) Czy miłość nie jest muzyką? (s. 261)

Lejb wierzący - jak wiemy - w siłę muzyki, szuka harmonii, w której złączą się anarchizująca etyka Jezusa ${ }^{48}$, chasydzki mistycyzm i filozofia Nietzschego. Harmonię te ustanowić może jedynie miłość, która uzyskuje tu wymiar uniwersalny i mesjański.

Daniel Grinberg postawił pytanie, czy istnieje związek między żydowską tradycją religijną a zaangażowaniem anarchistycznym czy szerzej - politycznym radykalizmem. Nie zajmując zdecydowanego stanowiska, przywołał przy tej okazji tezę Michaela Löwy’ego o „powinowactwach z wyboru” łączących myśl wolnościową (zarówno anarchizm, jak i wolnościowy komunizm) z żydowskim mesjanizmem. Co jednak istotne, Löwy z całą mocą zaprzecza istnieniu tych powinowactw na poziomie wschodnioeuropejskich aktywistów działających na „żydowskiej ulicy” i odnosi je wyłącznie do myśli takich filozofów, jak Martin Buber, Gershom Scholem, Walter Benjamin, Ernst Bloch czy - to francuski wyjątek - Bernard Lazare.

W Europie Wschodniej (...) sytuacja była zupełnie inna. Udział Żydów w ruchach rewolucyjnych był daleko większy niż w Europie Środkowej i, inaczej niż w Niemczech, nie ograniczony do intelektualistów (...). Wszyscy żydowscy rewolucyjni ideologowie, aktywiści i przywódcy, o różnych, nawet zwalczających się orientacjach politycznych (...) zgadzali się co do jednego: odrzucenia żydowskiej religii. Ich światopogląd był zawsze racjonalistyczny,

48 Nie wydaje się, mimo konsekwentnego używania terminu „Chrystus”, by Lejb traktował Jezusa jako postać boską. W kręgach anarchistycznych często zwracano uwagę na anarchizujący wymiar nauczania Jezusa, przeciwstawiającego miłość prawu. O reinterpretacji figury Jezusa w kulturze żydowskiej XIX i XX stulecia zob. Matthew Hoffman, From Rebel to Rabbi. Reclaiming Jesus and the Making of Modern Jewish Culture (Stanford: Stanford University Press, 2007). 
ateistyczny, świecki, oświeceniowy i materialistyczny. Żydowska tradycja religijna, mistycyzm kabały, chasydyzm i mesjanizm zupełnie ich nie interesowały ${ }^{49}$.

Choć zapewne jest to prawda w odniesieniu do rewolucyjnych przywódców w rodzaju Róży Luksemburg czy Lwa Trockiego, Grinberg zdaje się słusznie sugerować, że w wypadku żydowskich anarchistów na ziemiach polskich idea anarchistyczna mogła się jawić jako urzeczywistnienie mesjańskiej obietnicy. Wspominając Lejba, Icchak Goldkorn pisze, że przywodził on na myśl „ukrytego sprawiedliwego z żydowskich opowiadań ludowych”, pod którego szorstką powierzchownością bije „cudowne światło” ${ }^{50}$.

Hirszauge, Kaufman czy sam Lejb - wszyscy trzej pochodzili z rodzin chasydzkich i dla każdego z nich anarchizm wiązał się z porzuceniem religijności, ale niekoniecznie mesjańskiej perspektywy, którą raczej swoiście przekształcali ${ }^{51}$. W wypadku Lejba sytuacja jest zresztą jeszcze bardziej złożona. We wstępnych akapitach pamiętników opisuje on swoją edukację pod kierunkiem ojca prowadzącego nielegalny cheder ${ }^{52}$, potem studia w „małomiasteczkowych jesziwach” ${ }^{53}$. Podkreśla intensywność młodzieńczych przeżyć religijnych: „Byłem pochłonięty nauką chasydyzmu i pobożności (...). Przypominam sobie, że nie wychyliłem nosa poza «cztery łokcie halachy». Poza Torą ${ }^{54}$ i nabożeństwem nic mnie nie interesowało" (s. 243). To właśnie w kontekście nauki religii rodzi się jego miłość do muzyki i do śpiewu: „najszczęśliwszy byłem dzięki moim słodkim zmires”55 (s. 243).

Będąc człowiekiem dojrzałym, deklaruje się jako „zeświecczony” (s. 250), choć we wspomnieniach nie poświęca najmniejszej uwagi procesowi utraty wiary. Silnie kontrastuje to z opowieścią Kaufmana, gdzie w sposób typowy dla oświeceniowych żydowskich narracji

49 Michael Löwy, Redemption and Utopia. Jewish Libertarian Thought in Central Europe. A Study in Elective Affinity, tłum. Hope Heaney (Stanford: Stanford University Press, 1992), 41-42.

50 Goldkorn, Lodżer, 213. Zapewne mowa tu o lamedwowniku, jednym z 36 sprawiedliwych, którzy w każdym pokoleniu utrzymują świat w istnieniu, żyjąc w ukryciu pośród ludzi.

${ }^{51} \mathrm{Na}$ marginesie warto zauważyć, że podczas gdy wielu żydowskich anarchistów na ziemiach polskich pochodziło z ubogich chasydzkich rodzin i odebrało wykształcenie religijne, żydowskie anarchistki wywodziły się raczej ze środowisk zamożniejszych i zeświecczonych. Odmienna, jak się wydaje, dynamika zaangażowania kobiet i mężczyzn w ruch anarchistyczny zasługuje na szersze badanie w kontekście historii społecznej Żydówek i wzorców ich emancypacji.

52 Cheder - szkoła religijna, w której prowadzono nauczanie religijne na poziomie elementarnym; nierzadko, jak w wypadku ojca Lejba, nauka prowadzona była w mieszkaniu nauczyciela.

53 Jesziwa (jeszybot) - szkoła religijna dla młodych (przeważnie nastoletnich) nieżonatych mężczyzn, którzy ukończyli cheder.

54 Tora (hebr. Nauczanie, Pouczenie) - w węższym sensie Pięcioksiąg Mojżeszowy, pierwszych pięć ksiąg Biblii Hebrajskiej, w szerszym - całość Prawa religijnego (halachy).

55 Zmires (zmirot) - pieśni śpiewane przy szabasowym stole. 
autobiograficznych ${ }^{56}$ opisane zostały duchowe zmagania towarzyszące konfrontacji z nowoczesną, świecką kulturą europejską, której promienie „zdołały nawet przebić grube mury jeszibotu”. Wplatając wątek autobiograficzny w dzieje Żydowskiej Organizacji PPS, Kaufman pisze: „Młode me serce zadrżało: powstała tęsknota do oświaty. W duszy mojej zaczęła się walka między dwoma światami - starym a nowym. Po dwuletniej walce wewnętrznej udało mi się wyrwać ze świata fanatyzmu" ${ }^{57}$. Z jeszcze większą intensywnością, z której w tekście adresowanym do polskiego czytelnika Kaufman zrezygnował, ów proces przedstawiony jest w zachowanym w Archiwum Ringelbluma rękopisie tego fragmentu w języku jidysz:

Młode serce zadrżało: zapragnęło oświaty. Zaczęła się ciężka i gorzka walka między starym i nowym światem. Gdy pozycję w moim sercu zdobywał nowy świat, odrzucałem Talmud. W owym czasie zacząłem czytać szeroko wówczas znane haskalowe [oświeceniowe - P.L.] książki Smolenskina ${ }^{58}$. Stary świat nie składał broni, walczył wszystkimi możliwymi siłami, aby odzyskać swoją pozycję. Kiedy przeganiał z mojego serca nowy świat, wtedy ze łzami prosiłem Talmud o wybaczenie i po tysiąckroć obiecywałem mu, że go nigdy nie opuszczę. Przez dwa długie i bolesne lata te dwa światy walczyły ze sobą w moim sercu ${ }^{59}$.

Kaufman zaangażował się w działalność socjalistyczną w bardzo młodym wieku, a na jego lektury składały się, jak się wydaje, przede wszystkim dystrybuowane w tym środowisku teksty polityczne. W przypadku Lejba, którego biografia czytelnicza nie jest zresztą w żadnej mierze niezwykła, mamy do czynienia z wyborem popularnych dzieł literackich. Obok odniesień do tekstów biblijnych: psalmów, Księgi Koheleta czy Lamentacji Jeremiasza (można zresztą przypuszczać, że pamiętniki są do pewnego stopnia stylizowane na Lamentacje) znajdujemy liczne odwołania do szeroko czytanych dzieł literatury świeckiej - zarówno pisarzy języka jidysz, Mordechaja Spektora czy Mojsze Nadira (którego teksty były w repertuarze „Arara$\mathrm{tu}{ }^{60}$ ), jak i autorów polskich (Stanisław Przybyszewski) i europejskich (Oskar Wilde, Fiodor Dostojewski i przede wszystkim Leonid Andrejew, z którego melancholią współodczuwa tak silnie, że nazywa sam siebie jego „żywym ucieleśnieniem” [s. 241]). Nic nie wskazuje,

56 Por. Marcus Moseley, Being For Myself Alone: Origins Of Jewish Autobiography (Stanford: Stanford University Press, 2006).

57 Mojżesz Kaufman, „Przyczynki do historii Żydowskiej Organizacji PPS”, Niepodległość 12 (1935): 26.

58 Perec Smolenskin (1842-1885) - powieściopisarz i publicysta, redaktor wydawanego w Wiedniu pisma „Ha-Szachar” (Świt), jeden z twórców nowoczesnej żydowskiej idei narodowej, prekursor syjonizmu, przeciwnik z jednej strony chasydyzmu i religijnej ortodoksji, z drugiej zaś oświeceniowego asymilacjonizmu.

${ }^{59}$ Archiwum ŻIH, sygn. ARG I 1412 [bez paginacji] (s. 21 w skanie); tekst niepublikowany, tłum. Magdalena Siek na potrzeby niniejszego artykułu, za co serdecznie jej dziękuję.

60 Radziszewska, „Kultura”, XXII. 
by Lejb, tak jak Kaufman, zmagał się z konfliktem „dwóch światów” i by to zderzenie kultur zdecydowało o porzuceniu przez niego religii. Wydaje się, że większe znaczenie miała tu konfrontacja z trudami życia. Lejb czyni bowiem taką uwagę: „To, czego się można nauczyć w codziennej biedzie, jest czymś więcej niż Tora, uniwersytet i jesziwa razem wzięte” (s. 254). Koresponduje to z autobiograficzną narracją rok od Lejba młodszej Etli Bomsztyk, dziewczyny z Lipska nad Wisłą, od 14. roku życia pracującej w Warszawie jako służąca, aktywistki komunistycznej i organizatorki związków zawodowych służących żydowskich:

Tak płynęło moje życie w udręce, cierpieniach, bez słońca i radości, w wyniku czego przestałam wierzyć w boga, zaniechałam modlitwy, gdy przekonałam się, że w życiu moim nie ma poprawy, a zło nie ma końca, że muszę sama walczyć o swój byt. Wielkie było moje rozczarowanie w to ${ }^{61}$, co czytałam w modlitewniku, i w to, co opowiadała mama ${ }^{62}$.

Zarazem jednak, mimo deklarowanego zeświecczenia, stosunek Lejba do religii nie jest jednoznaczny. Cytaty z tekstów biblijnych, nawet afektacja, z jaką odnosi się do postaci Jezusa, w którym, przypomnijmy, widział prawdopodobnie anarchizującego moralistę („Uwielbiam prawdziwą, czystą miłość Chrystusa” [s. 241]), wpisują się w typowe narracje autobiograficzne tego okresu i nie muszą same w sobie świadczyć o zainteresowaniu wymiarem religijnym. W mieszkaniu Lejba przy ulicy „Kloacznej” na ścianach wiszą portrety „Marksa, Kropotkina, Dostojewskiego, Woltera i dwie fotografie byłych dziewczyn” (s. 256). A jednak w chwili miłosnego kryzysu Lejb nakłada tefilin i modli się (s. 261), przy drzwiach zaś przybija mezuzę, której jego rozrywkowi goście „nie mogli znieść (...), dwukrotnie ją zdejmowali, hańbili i ciskali o ziemię, a ja ją ponownie przybijałem, a oni bezczelni nie mogli mi tego wybaczyć” (s. 257).

\section{Miłość}

Jak widzieliśmy, Lejb uznaje miłość za siłę łączącą, zdolną ustanowić mesjańską wspólnotę. W tej perspektywie warto zatem rozpatrzyć jego pamiętniki jako opowieść o nieszczęśliwej miłości.

Jest tych miłości wiele. Pierwsza to Hendel, córka dozorcy domu, w którym mieszka jako chłopiec, druga i największa - Zelda, której dedykowany jest tekst pamiętników, potem

\footnotetext{
61 Tak w oryginale.

62 Piotr Laskowski, „«Zaczęłam filozofować, rozmyślać, szukać odpowiedzi na dręczące mnie kwestie». Wspomnienia Edwardy (Etli) Bomsztyk: biografia, emancypacja, polityka”, Praktyka Teoretyczna 1 (2017): 117.
} 
Riwkele, Fela, Masza... „W ogóle to u dziewcząt miałem powodzenie”, pisze Lejb ${ }^{63}$, lecz to powodzenie, iskra sympatii, trwa krótko, ledwie dwa spotkania:

Kiedy przychodziłem do nich po raz pierwszy, były w stosunku do mnie zimne, obojętne; za drugim razem posyłały mi już uśmiechy; za trzecim razem robiły mi tę przyjemność i szły ze mną na spacer na jakąś odległą, cichą ulicę. Za czwartym razem, który był jednocześnie ostatnim, kazały mi przerzucać gnój (s. 247).

Rodzi się podejrzenie, że mamy tu do czynienia z pewną figurą, że owa trajektoria nadziei i rozczarowania nie tyle odnosi się do konkretnych relacji powtarzających ten sam schemat, ile wyraża samotność i ból egzystencji. Widać to wyraźnie w śpiewanej przez Lejba pieśni „podróżnej”, której tekst zapisał w swym wspomnieniu Goldkorn. Warto zauważyć, że temat nieszczęśliwej miłości powraca też nieustannie w pieśniach ludowych jako wyraz egzystencjalnego cierpienia. Pieśni te mają jednak również wymiar polityczny - przeciwstawiane hymnom promowanym przez partie polityczne, same są głosem protestu i tęsknoty za innym światem, głosem niewpisującym się wszakże w formułę nowoczesnego aktywizmu. Przenikliwie dostrzegł to Icchak Meir Weissenberg (którego Córkę, jak widzieliśmy, śpiewał Lejb), gdy w swym najsłynniejszym opowiadaniu A Sztetl skontrastował „przywiezioną” z Warszawy pieśń (lid) par excellence polityczną Di szwue [Przysięga $]^{64}$ z piosenką (lidl) o nieodwzajemnionej miłości, podjętą na powrót przez miejscowych robotników, gdy tylko świadoma politycznie młodzież opuściła miasteczko ${ }^{65}$.

Uderzająca jest zbieżność między miłosnymi lamentami Lejba a zachowanym w Archiwum Ringelbluma obszernym zbiorem wierszy „starego” anarchisty Mojżesza Kaufmana ${ }^{66}$. Wiersze te, pisane w jidysz, banalne i schematyczne, o niskiej wartości literackiej, krążą nieustannie wokół tematu nieszczęśliwej miłości i samotności czyniącej życie nieznośnym.

63 Icchak Goldkorn zapisał w swym wspomnieniu, że z „dionizyjskiej triady: wino, kobiety, śpiew” Lejb cieszył się pierwszym i ostatnim, ponieważ jego powierzchowność, położenie społeczne i ogólna słabość fizyczna nie czyniły go atrakcyjnym (Goldkorn, Lodżer, 212).

64 O historii powstania i politycznym znaczeniu „Di szwue” zob. Józef Kozłowski, Śpiewy proletariatu polskiego (Warszawa: Polskie Wydawnictwo Muzyczne, 1977), 92-96.

65 I.M. Weissenberg, „A Shtetl”, w: A Shtetl and Other Yiddish Novellas, tłum. Ruth R. Wisse (Detroit: Wayne State University Press, 1986), 35-36.

66 W Archiwum Ringelbluma zachowały się również dwa numery radomskiego pisma literackiego „Literarisze grupe” z września 1930 i marca 1931 r. (sygn. ARG I 1391) oraz wydana przez to samo środowisko w 1928 r. jednodniówka „Dos literarisze Radom” (sygn. ARG I 1392). We wszystkich trzech opublikowano wiersze Kaufmana, podpisane używanym przez niego często pseudonimem Mosze Mezriczer (Kaufman urodził się w Międzyrzecu Podlaskim). Eleonora Bergman, której serdecznie dziękuję za zwrócenie mi uwagi na te dokumenty, zauważyła, że należały one zapewne do włączonej do Archiwum spuścizny Kaufmana. 
Wystarczy kilka przykładów: o zdradzie i porzuceniu przez ukochaną mówią m.in. Gekumen un awek [Przyszła i odeszła], Zol di erd cufalen [Niech ziemia się zapadnie], Bejde bagegenen mir [Dwa spotkania], Hostu fargesen [Zapomniałaś]. O rozczarowaniu życiem i ludźmi: Biter iz der wajn [Gorzkie jest wino], Majn lebn [Moje życie] czy Majne baglejter [Moi towarzysze], gdzie jedynymi towarzyszami życia poety są ciemna noc i zimne dni. W krótkim wierszu bez tytułu („Ich zing niszt mer...”) napisanym, jak wskazuje zanotowana przy nim data, w styczniu 1924 roku, a zatem - co istotne - w więzieniu, do którego trafił za działalność polityczną ${ }^{67}$, Kaufman powiada:

Nie śpiewam już miłosnych modlitw.

Kiedy przychodzą ciche wieczory,

Otulam się w czarny welon

I grzebię umarły dzień głęboko w sercu ${ }^{68}$.

Niska artystyczna wartość tych wierszy, ich wtórność, schematyczność, nawet nieporadność, nie zmieniają faktu, że mogły one stanowić formę, w której wyrażało się silnie przeżywane marzenie politycznego więźnia i aktywisty o nieosiągalnej wspólnocie. Wolno przypuszczać, że również konwencjonalne obrazowanie religijne, należące do zestawu najbardziej zużytych klisz literackich, przepełnione jest autentyczną tęsknotą, ożywiającą frazy pozbawione, zdawałoby się, religijnego znaczenia i nadającą im wymiar polityczny - obecny być może nawet w arcybanalnym wierszu Majn mizbejech [Mój ołtarz], opublikowanym w jednodniówce „Dos literarisze Radom":

Twa pierś - to ołtarz miłości,

Moje złamane serce jest zniszczone,

Ty jesteś zwycięzcą,

A ja twoją ofiarą (...).

Otwórz mi więc swój ołtarz,

Zabarwię go krwią,

67 Zob. Piotr Laskowski, „O materiałach Mojżesza Kaufmana w Archiwum Ringelbluma”, w: Archiwum Ringelbluma. Konspiracyjne Archiwum Getta Warszawy, t. 36: Uzupetnienia, oprac. Eleonora Bergman, Tadeusz Epsztein (Warszawa: Żydowski Instytut Historyczny, 2020), 364-374.

68 Archiwum ŻIH, sygn. ARG I 1415, k. 4; tłum. Magdalena Siek. Wszystkie przywołane wyżej wiersze pochodzą również z tej jednostki. 
I z cichą modlitwą miłosną,

Chcę umrzeć na twojej piersi ${ }^{69}$.

W pamiętnikach Lejba miłość ujmowana jest równie szablonowo. Nawet temat Zeldy, miłości najprawdziwszej, najważniejszej, powracający niczym leitmotiv od dedykacji do niemal ostatnich stron, podlega konwencjonalnej estetyzacji i wyrażony zostaje za pomocą cytatów z Mojsze Nadira i Stanisława Przybyszewskiego (s. 247). W tym kontekście uderzające jest zestawienie dwóch fragmentów, którym Lejb nadał formę listów. Narrator zwraca się tu w drugiej osobie do wybranych, szczególnie ważnych dlań postaci. Pierwszy list, krótki i schematyczny, adresowany jest właśnie do Zeldy (s. 255). Zaraz po nim następuje list do niejakiego Josla, w dalszej części tekstu pojawiającego się pod imieniem Mojsze Josl S. Ów list ma charakter szczególny, bardzo osobisty, wskazujący być może, że mamy tu do czynienia z afektami innego rodzaju niż te, o których mówiliśmy wyżej. Lejb mówi o Joslu: „towarzysz mego posłania i powiernik mych radości” (s. 257) i oskarża go o „dezercję” ze wspólnoty przy ulicy „Kloacznej”. Warto zacytować dłuższy fragment tego listu, zwracając uwagę na kontrastujący z przywołaniami Zeldy niezwykle silny ładunek emocjonalny i zastanawiający dobór odniesień literackich:

Joslu, teraz kieruję moje słowa do Ciebie (...). Wiesz, że moje przeżycia równe są cierpieniom Wertera i borykam się z nimi po dziś dzień. Moje wnętrze, które porównać można do wnętrza Doriana Graya, dostrzegło w Tobie jedynego mentora. Ty, który tak dobrze mnie rozumiałeś i świetnie wyczuwałeś każdy mój lęk (...). A potem zupełnie mnie porzucić! Wspólna nić, którą byliśmy związani w nieodległej przeszłości, wciąż we mnie trwa, tli się w mym sercu niczym niegasnący ogienek. Nawet gdy Cię wyzwałem od najgorszych, nie było to z nienawiści do Ciebie! (...) Chciałbym się z Tobą spotkać, nie gniewać się na Ciebie, ponieważ doprawdy nie mam nikogo poza Tobą (...). Jeśli masz pustkę w sercu i nic już do mnie nie czujesz, nie wspominasz mnie - postrzegasz tylko wokół siebie i wokół mnie nudę, zapewne nie będziesz mógł i nie zechcesz się ze mną spotkać (s. 255-256).

Do tego wymarzonego spotkania dojdzie i nie dojdzie zarazem. Stanowi ono pointę pamiętników. Lejb podaje nawet jego datę dzienną: 19 czerwca 1932 roku.

M.I.S. [Mojsze Josl S. - P.L.] spacerował dzisiaj po ulicy w eleganckim ubraniu z czerwoną różą w ręku. Biegł na plac Wolności, czy dlatego, że był bardzo zajęty, czy też dlatego, że

${ }^{69}$ Archiwum ŻIH, sygn. ARG I 1392, „Dos literarisze Radom. Ojsgabe far literatur un teater”, wrzesień 1928, s. 6. 
musiał być punktualnie na rendez-vous, tego nie wiem. W każdym razie nie miał czasu, by się przy mnie zatrzymać (s. 265).

Zauważmy, że domknięte w ten sposób pamiętniki otwiera motto zaczerpnięte z De profundis Oscara Wilde’a, tekstu pisanego w więzieniu po procesie, który wstrząsnął wieloma anarchistami: „Poza wesołością i śmiechem może kryć się temperament brutalny, oschły i nieczuły. Pod cierpieniem kryje się zawsze cierpienie tylko i nic więcej. Ból - w przeciwieństwie do rozkoszy - nie znosi maski”70.

David Halperin próbował ująć teoretycznie możliwość wpisania męskich przyjaźni (miłości) w historię męskiej homoseksualności ${ }^{71}$. W pisaniu takiej historii mierzyć się musimy i z barierami terminologicznymi (historycznymi uwarunkowaniami określającymi znaczenie terminów „homoseksualizm” czy „homoseksualność”, adekwatnością tych kategorii), i grą milczenia i sygnalizowania podejmowaną przez twórców naszych źródeł. Niezwykle rzadko spotykamy jasne, otwarte autodeklaracje, zazwyczaj mamy do czynienia z tropami, których odczytanie wymaga tego, co Carlo Ginzburg nazwał „niższą intuicją” (intuizione bassa). Owa intuicja, będąca sama w sobie „niebezpiecznym terminem”, należy do paradygmatu poznawczego, który zdecydowanie wykracza poza rygory pozytywistycznej naukowości i zarazem pozwala dostrzec przestrzenie wyciszenia, jakie pozytywistyczna metodologia ustanawia i podtrzymuje ${ }^{72}$.

Wiemy dobrze, że anarchoindywidualizm przyciągał wiele osób nieheteronormatywnych. Najważniejsi aktywiści tego nurtu, John Henry Mackay czy Émile Armand, odważnie i otwarcie podejmowali kwestię homoseksualności. Armand w broszurze L'homosexualité, l'onanisme et les individualistes pisał: „Człowiek zdolny do refleksji nie zadowala się słowami «sprzeczne z dobrymi obyczajami», «niegodne» - chce wiedzieć, co zbrodniczego jest w akcie, który nie wiąże się ani z bólem, ani z przemocą”73. Również postulat „wolnej miłości” zajmował w refleksji anarchoindywidualistycznej miejsce wyróżnione, dzięki wspomnieniu Icchaka Goldkorna wiemy zaś, że był to temat poruszany w kręgu „Lejba Anarchisty”.

70 Oscar Wilde, De Profundis. Listy i impresje więzienne, tłum. Róża Centnerszwerowa (Warszawa: Vita Nuova, 1922), 28.

71 David Halperin, „Jak uprawiać historię męskiego homoseksualizmu?”, tłum. Joanna Bednarek, w: Teorie wywrotowe. Antologia przekładów, red. Agnieszka Gajewska (Poznań: Wydawnictwo Poznańskie, 2012), 605-662, na ten temat 612-613 i 626-631.

72 Carlo Ginzburg, „Tropy. Korzenie paradygmatu poszlakowego”, tłum. Tadeusz Sierotowicz, Zagadnienia Filozoficzne w Nauce 39 (2006): 8-65. Metodologicznych inspiracji dostarczyć może też Leo Strauss, „Prześladowanie i sztuka pisania”, w: tegoż, Sokratejskie pytania, tłum. Paweł Maciejko (Warszawa: Fundacja „Aletheia”, 1998).

73 Émile Armand, L’homosexualité, l'onanisme et les individualistes (Paris: Édition de l'En dehors, 1931 ), 4. 
Niezależnie od tego, czy chcielibyśmy uznać Lejba za osobę homo- lub biseksualną, nie ulega wątpliwości, że wyłaniająca się z jego pamiętników konstrukcja męskiej podmiotowości obejmuje cechy dokładnie przeciwne tym, na których opiera się męska płeć kulturowa zdefiniowana przez zachodnią nowoczesność. Cechy te - delikatność, emocjonalność (nawet emocjonalne rozedrganie), fizyczna słabość, bierność - przypisywane były religijnym Żydom z Europy Wschodniej, a także homoseksualnym mężczyznom ${ }^{74}$. I jedni, i drudzy znajdowali się po tej samej - „kobiecej”, „orientalnej” - stronie równania. Podczas gdy nowoczesne żydowskie ruchy polityczne powiązały emancypację z dominującym modelem męskości - czy będzie to syjonizm podejmujący koncepcję Muskeljudentum Maxa Nordaua, czy heroizujący robotnika socjalizm i komunizm - anarchizm Lejba, a przecież także anarchizm Kaufmana czy Hersza Menesa, pozostawia miejsce na słabość i melancholię. Być może z tej perspektywy należy również patrzeć na specyficzne związki Lejba z chasydzką religijnością, która dawała przestrzeń dla realizowania wzoru słabej męskości, jak też otwierała przestrzeń dla artykulacji, jakkolwiek zapośredniczonej, pragnienia homoseksualnego ${ }^{75}$.

\section{Zakończenie}

Choć do anarchoindywidualizmu Lejba większość międzywojennych żydowskich anarchistów odnosiła się z dystansem, jeśli nie niechęcią, możemy dostrzec, że i w wypadku Lejba, i „starych” ich sposób bycia w świecie uderzająco różni się od wzorca, który znajdujemy w autobiograficznych wypowiedziach działaczy komunistycznych i socjalistycznych. W narracjach tworzonych wewnątrz rewolucyjnych partii zaangażowanie polityczne daje siłę, pozwala przezwyciężyć poczucie niemocy, rozpoznać się w kolektywnym działaniu ${ }^{76}$. Sprawa, socjalistyczny czy komunistyczny ideał, wydobywa jednostkę z upodlenia codziennego życia i powołuje ją do bohaterskiego, aktywnego, „męskiego” tworzenia historii (historii, której

74 Zob. Daniel Boyarin, Unheroic Conduct. The Rise of Heterosexuality and the Invention of the Jewish Man (Berkeley: University of California Press, 1997), za którym tu podążam; ważne uwagi polemiczne, zob. Hillel J. Kieval, „Imagining 'Masculinity' in the Jewish Fin de Siècle”, Studies in Contemporary Jewry 16 (2000): 142-155.

75 Zob. Ofri Ilany, „Homo-Semitism: Jewish Men, Greek Love and the Rise of Homosexual Identity”, w: Internal Outsiders - Imagined Orientals? Antisemitism, Colonialism and Modern Constructions of Jewish Identity, red. Ulrike Brunotte, Jürgen Mohn, Christina Späti (Würzburg: Ergon Verlag, 2017), 131-142. Niezwykłym przykładem takiej konceptualizacji chasydyzmu jest naznaczone doświadczeniami autobiograficznymi dzieło Jiříego (Georga) Mordechaja Langera, Die Erotik der Kabbala (Prag: Josef Flesch, 1923). O Langerze zob. Shaun Jacob Halper, „Coming Out of the Hasidic Closet. Jiři Mordechai Langer (1894-1943) and the Fashioning of Homosexual-Jewish Identity”, Jewish Quarterly Review 101 (2011), 2: 189-231.

76 Wiktor Marzec, „The Birth of the Militant Self. Working-Class Memoirs of Late Russian Poland”, East Central Europe 46 (2019): 29-51; zob. też: tenże, Rebelia i reakcja. Rewolucja 1905 roku i plebejskie doświadczenie polityczne (Łódź-Kraków: Wydawnictwo Uniwersytetu Łódzkiego Universitas, 2016), 194-222. 
mechanizm i cel został rozpoznany). W przypadku anarchistów rzecz przedstawia się dokładnie odwrotnie - mamy tu do czynienia $\mathrm{z}$ akcentowaniem słabości, niemocy, wieczystego rozczarowania. Ideał pozostaje zawsze niespełniony, stając się źródłem cierpienia. Anarchista skazany jest na melancholię. Nie przypadkiem smutna pieśń, wiersz, są tak chętnie wybieraną formą wyrazu. Zachowaną we wspomnieniu Goldkorna anarchistyczną pieśń śpiewaną przez Lejba, pieśń, z którą koresponduje cały jego pamiętnik, zestawić można z wierszem Hersza Menesa. Menes umieścił go jako motto swej książki poświęconej filozofii Nietzschego (fascynacja Zaratustrą jest zresztą również wspólna Lejbowi i Menesowi). Eliezer Hirszauge, który tę książkę wydał własnym sumptem ${ }^{77}$, zacytował ów wiersz w poświęconym Menesowi rozdziale wspomnień, wskazując, że „w tych kilku wersach autor znakomicie, ostrymi kreskami, nakreślił swój portret”:

Poprzez życia ciężką drogę,

Utrudzony jam wędrowiec.

Nabrzmiały tęsknotą, myśli ciągłym ruchem,

Wygłodzony na ciele i duchu.

Piłem ja ci z tego źródła -

Lecz mi ciągle było mało.

Podziel, proszę, Czytelniku, mą tęsknotę, me pragnienie!

Może wespół będzie lepiej? ${ }^{78}$

Ostatnią nadzieją pozostaje dla anarchisty osoba, która będzie czytać jego słowa ${ }^{79}$ - to jedyna szansa na ulotną wspólnotę, harmonię słów i dźwięków wyrażających niespełnialną tęsknotę.

77 Hersz Menes-Frajnd, Niczes filozofie (Warsze: nakładem El. Hirszauge, 1939).

78 Hirszauge, Spetniajace, 32-33.

79 Por. uwagi Emmy Goldman: „Zdawało mi się, że za sprawą daru wymowy, zapału i żarliwości słowa (...) z taką siłą wrażały się w słuchające masy, że nigdy nie zatrą się w ludzkich umysłach i duszach (...). Nie wierzę już w cudowną siłę słowa mówionego (...). Związek między pisarzem a czytelnikiem jest bardziej zażyły (...). Nie jestem nastawiona aż tak optymistycznie, by liczyć na tylu czytelników, ilu miałam słuchaczy. Wolę jednak, żeby moje słowa trafiły do kilku osób naprawdę łaknących wiedzy, niż do wielu, które pragną być jedynie zabawiane”. Emma Goldman, Anarchizm i inne eseje, tłum. Jagoda Dolińska, Andrzej Grzybowski, Piotr Laskowski, Maciej Łagodziński, Gabriela Łazarkiewicz, Sebastian Matuszewski (Poznań: Oficyna Wydawnicza Bractwa Trojka, 2015), 43-44. 
Bibliografia

Źródła niepublikowane:

International Institute of Social History w Amsterdamie. Federación Anarquista Ibérica Archives, Archivo de la oficina de propaganda exterior CNT/FAI, Augustin Souchy, sygn. 41D.

Archiwum Żydowskiego Instytutu Historycznego im. Emanuela Ringelbluma w Warszawie. Archiwum Ringelbluma, sygn. ARG I 1412, ARG I 1415, ARG I 1392.

Źródła publikowane, wspomnienia, opracowania:

Archiwum Ringelbluma. Konspiracyjne Archiwum Getta Warszawy. T. 3: Relacje z Kresów, oprac. Andrzej Żbikowski. Warszawa: Żydowski Instytut Historyczny IN-B, 2000.

Armand, Émile. L'homosexualité, l'onanisme et les individualistes. Paris: Édition de l'En dehors, 1931. Avrich, Paul. The Russian Anarchists. Princeton: Princeton University Press, 1967.

Boyarin, Daniel. Unheroic Conduct. The Rise of Heterosexuality and the Invention of the Jewish Man. Berkeley: University of California Press, 1997.

Chwedoruk, Rafał. Ruchy i myśl polityczna syndykalizmu w Polsce. Warszawa: Dom Wydawniczy Elipsa, 2011.

Cygielstrejch, Adam. „Twórczość psychologiczna Edwarda Abramowskiego”. Przegląd Filozoficzny 22 (1919): 1-12.

Fuks, Chaim Leib. Lodż szel majle. Tel Awiw: I.L. Perec Farlag, 1972.

Ginzburg, Carlo. „Tropy. Korzenie paradygmatu poszlakowego”. Tłum. Tadeusz Sierotowicz. Zagadnienia Filozoficzne w Nauce 39 (2006): 8-65.

Goldkorn, Icchok. Lodżer portretn: umgekumene jidisze szrajber un tipn. Tel Awiw: Ha-Menora, 1963.

Goldman, Emma. Anarchizm i inne eseje. Tłum. Jagoda Dolińska, Andrzej Grzybowski, Piotr Laskowski, Maciej Łagodziński, Gabriela Łazarkiewicz, Sebastian Matuszewski. Poznań: Oficyna Wydawnicza Bractwa Trojka, 2015.

Gonczarok, Mosze. Piepiel naszich kostrow. Oczerki istorii jewriejskowo anarchistskowo dwiżenija (idisz-anarchizm). Jerusalim: Izdatielstwo „Problemen”, 2002.

Grave, Jean. L'individu et la société. Paris: P.-V. Stock, 1897.

Grinberg, Daniel. „Formes de la militance juive radicale en Pologne”. W: Juifs et anarchistes. Histoire d'une rencontre, red. Amedeo Bertolo, 159-171. Tłum. Patricia Farazzi, Marianne Enckell, Jean-Manuel Traimond. Paris-Tel Aviv: Éditions de l’Eclat, 2008.

Grinberg, Daniel. „Il radicalismo ebraico in Polonia”. W: L'anarchico e l'ebreo. Storia di un incontro, red. Amedeo Bertolo, 165-178. Milano: Elèuthera, 2001.

Grinberg, Daniel. Ruch anarchistyczny w Europie Zachodniej 1870-1914. Warszawa: Wydawnictwo Naukowe PWN, 1994.

Halper, Shaun Jacob. „Coming Out of the Hasidic Closet. Jiři Mordechai Langer (1894-1943) and the Fashioning of Homosexual-Jewish Identity”. Jewish Quarterly Review 101 (2011), 2: 189-231. 
Halperin, David. „Jak uprawiać historię męskiego homoseksualizmu?”. Tłum. Joanna Bednarek. W: Teorie wywrotowe. Antologia przekładów, red. Agnieszka Gajewska, 605-662. Poznań: Wydawnictwo Poznańskie, 2012.

Hirszauge, Eliezer. Spełniające się marzenie. Wspomnienia o ruchu anarchistycznym w Polsce 19281946. Tłum. Magdalena Siek. Poznań: Oficyna Wydawnicza Bractwa Trojka, 2019.

Hoffman, Matthew. From Rebel to Rabbi. Reclaiming Jesus and the Making of Modern Jewish Culture. Stanford: Stanford University Press, 2007.

Ilany, Ofri. „Homo-Semitism: Jewish Men, Greek Love and the Rise of Homosexual Identity”. W: Internal Outsiders - Imagined Orientals? Antisemitism, Colonialism and Modern Constructions of Jewish Identity, red. Ulrike Brunotte, Jürgen Mohn, Christina Späti, 131-142. Würzburg: Ergon Verlag, 2017.

Kaufman, Mojżesz. „Początki roboty żydowskiej PPS”. Niepodległość 7 (1933): 335-350.

Kaufman, Mojżesz. „Przyczynki do historii Żydowskiej Organizacji PPS”. Niepodległość 12 (1935): $22-52$.

Kieval, Hillel J. „Imagining 'Masculinity' in the Jewish Fin de Siècle”. Studies in Contemporary Jewry 16 (2000): 142-155.

Kozłowski, Józef. Śpiewy proletariatu polskiego. Warszawa: Polskie Wydawnictwo Muzyczne, 1977. Langer, Georg. Die Erotik der Kabbala. Prag: Josef Flesch, 1923.

Laskowski, Piotr. „O materiałach Mojżesza Kaufmana w Archiwum Ringelbluma”, w: Archiwum Ringelbluma. Konspiracyjne Archiwum Getta Warszawy, t. 36: Uzupełnienia, oprac. Eleonora Bergman, Tadeusz Epsztein (Warszawa: Żydowski Instytut Historyczny, 2020), 364-374.

Laskowski, Piotr. „ «Zaczęłam filozofować, rozmyślać, szukać odpowiedzi na dręczące mnie kwestie». Wspomnienia Edwardy (Etli) Bomsztyk: biografia, emancypacja, polityka”. Praktyka Teoretyczna 1 (2017): 84-129.

Löwy, Michael. Redemption and Utopia. Jewish Libertarian Thought in Central Europe. A Study in Elective Affinity. Tłum. Hope Heaney. Stanford: Stanford University Press, 1992.

Maitron, Jean. Le mouvement anarchiste en France. T. 1: Des origines à 1914. Paris: Gallimard, 1975.

Malatesta, Errico. „Lo sciopero armato”. Il lungo esilio londinese 1900-1913. Milano: Zero in Condotta, 2015.

Marek, Paweł Lew. Na krawędzi życia. Wspomnienia anarchisty 1943-44. Kraków: Wydawnictwo „Dąb”, 2006.

Marks, Karol, Fryderyk Engels. „Ideologia niemiecka”. Tłum. Salomon Filmus, Kazimierz Błeszyński. W: Karol Marks, Fryderyk Engels, Dzieła. T. 3, 9-619. Warszawa: Książka i Wiedza, 1961.

Marks, Karol, Fryderyk Engels. „Święta rodzina, czyli krytyka krytycznej krytyki. Przeciwko Brunonowi Bauerowi i spółce”. Tłum. Salomon Filmus, Tadeusz Kroński. W: Karol Marks, Fryderyk Engels, Dzieła. T. 2, 3-262. Warszawa: Książka i Wiedza, 1961. 
Marzec, Wiktor. Rebelia i reakcja. Rewolucja 1905 roku i plebejskie doświadczenie polityczne. ŁódźKraków: Wydawnictwo Uniwersytetu Łódzkiego Universitas, 2016.

Marzec, Wiktor. „The Birth of the Militant Self. Working-Class Memoirs of Late Russian Poland”. East Central Europe 46 (2019): 29-51.

„Memuary albo okruchy z życia Lejba”. Tłum. Anna Jakimszyn-Gadocha. W: Sztetl, szund, bunt i Palestyna. Antologia twórczości literackiej Żydów w Łodzi (1905-1939), red. Krystyna Radziszewska, Dariusz Dekiert, Ewa Wiatr, 240-265. Łódź: Wydawnictwo Uniwersytetu Łódzkiego, 2017. Menes-Frajnd, Hersz. Niczes filozofie, Warsze: nakładem El. Hirszauge, 1939.

Moseley, Marcus. Being For Myself Alone: Origins Of Jewish Autobiography. Stanford: Stanford University Press, 2006.

Patten, John, red. Yiddish Anarchist Bibliography. London-Cambridge: Kate Sharpley Library, 1998.

Podręczny rejestr handlowy 1926. Łódź: Nakładem Wydawnictwa Księgi Prawomocnych Podpisów Przemysłu, Handlu i Finansów, 1926.

Puławer, Mosze. Ararat. Tel Awiw: I.L. Perec Farlag, 1972.

Radziszewska, Krystyna, Dariusz Dekiert, Ewa Wiatr, red. Sztetl, szund, bunt i Palestyna. Antologia twórczości literackiej Żydów w Łodzi (1905-1939). Łódź: Wydawnictwo Uniwersytetu Łódzkiego, 2017.

Rappaport, Herman. Anarchizm i anarchiści na ziemiach polskich do 1914 roku. Warszawa: Państwowe Wydawnictwo Naukowe, 1981.

Strauss, Leo. „Prześladowanie i sztuka pisania”. W: Leo Strauss, Sokratejskie pytania. Tłum. Paweł Maciejko, 107-121. Warszawa: Fundacja „Aletheia”, 1998.

Trunk, Jechiel Jeszaja. Pojln. Obrazy i wspomnienia z Łodzi. Tłum. Anna Clarke. Łódź: Wydawnictwo Tygiel Kultury, 1997.

Weissenberg, I.M. „A Shtetl”. W: A Shtetl and Other Yiddish Novellas. Tłum. Ruth R. Wisse. Detroit: Wayne State University Press, 1986.

Wierzchoś, Dariusz, Michał Przyborowski. „Anarchizm polski w latach 1918-1926. Na drodze do utworzenia Anarchistycznej Federacji Polski”. Scripta Historica 22 (2016): 191-210.

Wierzchoś, Dariusz, Michał Przyborowski. Machno w Polsce. Poznań: Oficyna Wydawnicza Bractwa Trojka, 2012.

Wilde, Oscar. De Profundis. Listy i impresje więzienne. Tłum. Róża Centnerszwerowa. Warszawa: Vita Nuova, 1992.

Zackiewicz, Grzegorz. Syndykalizm w polskiej refleksji i rzeczywistości politycznej I połowy XX wieku. Kraków: Avalon, 2013.

Zandberg, Adrian. „Anarchistyczna Federacja Polski. Polscy anarchiści w dwudziestoleciu międzywojennym”. Przegląd Historyczny 93 (2002), 1: 31-52.

Zimmer, Kenyon. Immigrants against the State. Yiddish and Italian Anarchism in America. UrbanaChicago-Springfield: University of Illinois Press, 2015. 


\section{Rebellion and melancholy. An image of anarchist life in Memuarn fun Leybn}

Summary

The subject of the paper is a unique autobiographical text written in interwar Poland by a Jewish anarchist. A small booklet in Yiddish, Memuarn oder shpliters fun a lebn fun Leybn (also known as Memuarn fun Leybn) was published in 1933 in Łódź; the Polish translation appeared in 2017 under the title Memuary albo okruchy z życia Lejba. In the first part of the paper the author of the text, Leyb Berkenvald, known as "Leyb the Anarchist," is identified and described, with a focus on the social milieu to which he belonged, and his position on the map of interwar anarchism. In the second part, Leyb's autobiography is analyzed from the perspective of the microhistory of affects to reveal an alternative form of male subjectivity emerging from the text, which countered the dominant, heteronormative model of masculinity. This specific form of subjectivity is interpreted - both in its hopes and disappointments - in the context of an unattainable messianic community which Leyb strove to conceive.

Keywords

Leyb Berkenvald, "Leyb the Anarchist," Jewish anarchism, individualist

anarchism, history of affects, queerstory

Translated by Piotr Laskowski

PROSIMY O CYTOWANIE TEGO ARTYKUŁU JAKO:

Piotr Laskowski, „Bunt i melancholia. Obraz życia anarchisty w Memuarn fun Lejbn”, Autobiografia: Literatura. Kultura. Media 1 (2020), 14: 185-215. DOI: 10.18276/au.2020.1.14-10 